\title{
WARTOŚCI SPOŁECZNE W EDUKACJI DLA ZRÓWNOWAŻONEGO ROZWOJU
}

\begin{abstract}
Streszczenie: Edukacja dla zrównoważonego rozwoju stanowi ważną strategię społeczną, która ma na celu wspieranie koniecznych zmian będących odpowiedzią na globalne zagrożenia społeczno-gospodarcze współczesnego świata. Podkreśla potrzebę podejścia holistycznego, łączącego problemy związane z rozwojem z kwestiami społecznymi i środowiskowymi. Celem artykułu jest próba ukazania potrzeby i znaczenia obecności wartości społecznych w idei zrównoważonego rozwoju, która poprzez edukację zmierza do wywoływania w ludziach zmian o charakterze lokalnym i globalnym. Zmiany te mają prowadzić do budowania lepszego świata opartego na większej integracji ze środowiskiem i w sprawiedliwym społeczeństwie, nie tylko dla współczesnych, lecz także przyszłych pokoleń.
\end{abstract}

Słowa kluczowe: zrównoważony rozwój; edukacja dla zrównoważonego rozwoju; wartości społeczne; środowisko; wspólnota; dobro wspólne.

\section{Wstęp}

Społeczny aspekt zrównoważonego rozwoju, na którym koncentruje się autor tych rozważań, podkreśla środowiskowe uwarunkowania zaspokajania podstawowych potrzeb rozwojowych człowieka. Środowisko (wychowawcze) jest zarówno naturalnym miejscem wydarzeń wychowawczych, jak i miejscem planowanych działań wychowawczych, co oznacza świadome przekształcanie tego miejsca. Środowisko wychowawcze jest zatem miejscem praktyki wychowawczej, tzn. zaplanowanej w nim pedagogicznej obecności. Jedną z perspektyw interpretacyjnych dla rekonstrukcji rzeczywistości społecznej jest perspektywa pedagogiczna. Jest ona charakterystyczna, ponieważ z jednej strony opisuje te miejsca (identyfikuje, diagnozuje), z drugiej zaś interpretuje je jako przestrzenie aktywne, oddziałujące na człowieka, co więcej, wpływające na jego działanie, zwłaszcza w aspekcie realizowanych przez niego wartości. Dlatego w pedagogice perspektywa ta nazywana 
jest środowiskiem wychowawczym ze względu na jej aksjologiczną perspektywę (Cichosz 2014, s. 219-220).

We współczesnym świecie splatają się różnego rodzaju megawpływy: ideologiczne, społeczno-kulturowe, technologiczne, gospodarcze, rynkowe. Zakres i intensywność tych procesów sprawia, że tworzą się nowe, globalne reguły i mechanizmy rządzące światem. Prowadzą one do zauważalnych dychotomii w życiu jednostek, grup społecznych i całych społeczeństw. Z jednej strony postępująca i chyba już nieodwracalna współzależność gospodarcza czy społeczno-kulturowa, z drugiej zaś widoczny kryzys, a nawet atrofia więzi międzyludzkich, fragmentaryzacja i relatywizacja życia etycznego, rozpad tożsamości. Na tym tle tworzy się i funkcjonuje nowe środowisko (wychowawcze) człowieka. W wymiarze społeczno-kulturowym, jak zauważa Wiesław Theiss, globalizacja współtworzy bliższe, bezpośrednie i pośrednie środowisko życia jednostek i szerszych grup społecznych. W takiej sytuacji ujawnia się potrzeba dążenia do tego, aby to środowisko było jak najbardziej „[...] bezpieczne, tzn. takie, w którym ludzie wiedzą, jak postępować, i aby nie zagrażało ono podmiotowości i tożsamości człowieka, należy obecny świat zrozumieć oraz przygotować do funkcjonowania w nim. Dlatego jednym z głównych zadań szeroko rozumianej edukacji jest ograniczenie niebezpieczeństw, które grożą człowiekowi ze strony różnych i sprzecznych, bardzo intensywnych globalnych wpływów, a z drugiej strony - optymalne wykorzystanie nieograniczonych wręcz szans i możliwości rozwojowych, jakie przynosi globalizacja" (Theiss 2016, s. 18-19).

W wyniku zasygnalizowanych wyżej wpływów ideologicznych znaczniej zmianie ulegają miejsce i rola człowieka w środowisku. Różnicę w postrzeganiu pozycji człowieka w środowisku, rozumianą jako poglądy i koncepcje, opisuje idea posthumanizmu. Miejsce człowieka, będącego centralnym punktem odniesienia w świecie, miarą wszechrzeczy, w ujęciu antropocentrycznym nie jest już takie oczywiste (Zawojski 2017; por. Braidotti 2014). Z punktu widzenia idei posthumanizmu dotychczas akceptowany system norm społecznych i wartości traci na znaczeniu i zostaje zakwestionowany (Odrowąż-Coates 2015). W tym zglobalizowanym świecie, pełnym różnorodności i przeciwieństw, nierzadko w aksjologicznym chaosie, zadaniem edukacji dla zrównoważonego rozwoju jako edukacji holistycznej jest także kształtowanie systemu norm i wartości społecznych.

\section{Zrównoważony rozwój a potrzeba edukacji}

Globalizacja sama w sobie nie stanowi jeszcze przedmiotu zainteresowania dla pedagogiki, ale będzie już nim wpływ globalizacji na sferę szeroko rozumianej edukacji. Pedagogika nie jest kreatorem zjawisk i procesów globalizacyjnych, lecz powinna je uwzględniać w swoich teoriach, włącznie z edukacją globalną. Biorąc pod uwagę definicję edukacji globalnej, wypracowanej przez Ministerstwo Edukacji Narodowej, należy mieć na uwadze działalność edukacyjną kształtującą postawy 
otwartości i solidarności, rozbudzającą ciekawość poznawczą świata, jak też propagowanie wiedzy o problemach globalnych. W takim ujęciu edukacja globalna staje się pojęciem parasolowym dla następujących inicjatyw: edukacja rozwojowa, edukacja międzykulturowa, edukacja dla pokoju czy edukacja na rzecz zrównoważonego rozwoju (Babicki 2016, s. 39-40). Zadaniem edukacji globalnej jest zatem wspieranie jednostki w przygotowaniu jej do myślenia i działania w warunkach ryzyka. Dlatego wskazane jest, aby dostarczała ona ludziom, zwłaszcza młodym, wiedzy o globalizacji, globalnym rozwoju, przyczynach i skutkach nierówności społecznych i ubóstwa w oparciu o perspektywę zrównoważonego rozwoju (Scheunpflug 2004, s. 39-45). Mówiąc o edukacji dla zrównoważonego rozwoju, należy także pamiętać o tym, że zjawiska globalizacji prowadzą do bardzo istotnych zawirowań m.in. w sferze aksjologii wychowania.

Pojęcie zrównoważonego rozwoju jest nieostre, ponieważ odnosi się m.in. do różnych obszarów ludzkiej egzystencji, np. obszaru ekologicznego, obszaru ekonomicznego czy obszaru społeczno-kulturowego. Wydaje się, że najbardziej powszechnie używaną definicją dla określenia zrównoważonego rozwoju jest sformułowana w 1987 roku w raporcie pt. „Nasza wspólna przyszłość” opublikowanego przez Światową Komisję Środowiska i Rozwoju ONZ, która określa go jako „proces mający na celu zaspokojenie aspiracji rozwojowych obecnego pokolenia w sposób umożliwiający realizację tych samych dążeń następnym pokoleniom” (UNESCO, 8.06.2018). Wyłaniające się pojęcie zrównoważonego rozwoju odnosi się do kwestii ekologicznych (ochrony środowiska), racjonalnej eksploatacji zasobów naturalnych, jak też do rozwoju społecznego (dostęp do edukacji, walka z biedą czy ochrona zdrowia). Wiedza z zakresu przywołanych tutaj zagadnień i procesów, zidentyfikowanych jako zrównoważony rozwój, wymaga podejmowania działań edukacyjnych, które będą przygotowywać ludzi do funkcjonowania w zglobalizowanych społeczeństwach.

Realizacja potrzeb rozwojowych jest uwarunkowana dobrymi relacjami między ludźmi, którzy dbają o udostępnianie im podstawowych dóbr. Powszechne jest założenie, że tylko jednostki podejmujące działania na rzecz dobra wspólnego, kierujące się pewnym imperatywem moralnym, z powodu uznawanych wartości wyższych mogą przejąć odpowiedzialność za innych ludzi (Szadzińska 2015, s. 129). Dla realizacji tak rozumianych działań prospołecznych w ramach zrównoważonego rozwoju należałoby podjąć odpowiednie inicjatywy edukacyjne. Międzynarodowe organizacje, takie jak: ONZ czy UNESCO, określają edukację dla zrównoważonego rozwoju jako:

- edukację, która umożliwia uczącemu się zdobywanie umiejętności, wiedzy i przymiotów zapewniających mu trwały rozwój;

- edukację jednakowo dostępną na wszystkich szczeblach i we wszelkich społecznych kontekstach (rodzinnych, szkolnych, zawodowych, w lokalnej społeczności); 
- edukację budującą odpowiedzialność obywatelską i promującą demokrację poprzez uświadomienie jednostce jej praw i obowiązków;

- $\quad$ edukację opartą na zasadzie nauki przez całe życie;

- edukację wspierającą równomierny rozwój jednostki (UNESCO).

Tak sformułowane oczekiwania społeczne są możliwe do realizacji przy założeniu, że edukacja dla zrównoważonego rozwoju zostanie oparta na określonych wartościach (społecznych). Podmiotowe uczestnictwo człowieka w urzeczywistnianiu zrównoważonego rozwoju wyraża się w planowaniu, organizowaniu, realizowaniu i weryfikowaniu działania w środowisku społecznym. Działania zmierzające do zmiany rzeczywistości, ulepszania świata w oparciu o idee zrównoważonego rozwoju często wymagają przewartościowania w postrzeganiu osoby ludzkiej i jej otoczenia. Oznaczać to może przyjęcie założeń odnoszących się do potrzeby kształtowania takich cech osobowości, jak: empatia, wrażliwość na potrzeby drugiego człowieka, postawa miłości do innych (caritas). Cechy te uzdalniają człowieka do bezinteresowności, zaangażowania na rzecz dobra wspólnego i współpracy. Jak podkreśla Holger Rogall (2010, s. 195), umiejętność współpracy pomaga osiągać określone cele, zwłaszcza te dalekosiężne. Współpraca jest także czynnikiem, który podnosi poziom bezpieczeństwa i szczęścia człowieka. W związku z tym, zdaniem autora, kształtowanie norm społecznych powinno być ukierunkowane nie tyle na osiąganie celów, ile raczej na myślenie o budowaniu wspólnoty. Ta zaś jawi się jako normatywny ideał, który ukazuje, w jaki sposób powinny wyglądać relacje społeczne. Doświadczenie wspólnoty opiera się na działaniach zmierzających do budowania społecznej całości i powszechnej identyfikacji. Oznacza to także zanikanie egoistycznej rywalizacji, która bardzo często charakteryzuje współczesne społeczeństwa. Jak przekonuje Ferdynand Tönnies (1988, s. 123-127), wspólnota organizuje się wokół „woli naturalnej”, czyli nie do końca świadomej, instynktownej siły, która stymuluje i motywuje jednostki do poświęcania swojego wysiłku i czasu do służby innym. Postawa członków wspólnoty jest regulowana przez wspólne normy i wartości oraz przez wzajemną odpowiedzialność. Bohdan Skrzypczak zauważa jednak, że coraz częściej mamy do czynienia ze zjawiskiem nowej wspólnotowości, która oznacza budowanie tożsamości jednostek poprzez uczestnictwo w różnych wspólnotach emocjonalnych. Ten nowy typ wspólnotowości określany jest, według pojęcia stworzonego przez Michela Maffesoliego, jako „nowe plemiona” (2008). Tego rodzaju wspólnota zapewnia człowiekowi poczucie sensu, proponuje mu określony styl życia i identyfikację z innymi ludźmi. Poprzez aktywne uczestnictwo w danej społeczności jednostka może kształtować swoją tożsamość, zaś przynależność emocjonalna powoduje, że indywidualizm i egoizm ustępują miejsca postawie solidarności, sprawiedliwości społecznej, dialogu itp. W odróżnieniu od starych wspólnot nowe nie kontrolują swoich członków, lecz ich siła polega na integracji ludzi poprzez budowanie sieci komunikacyjnej i poczucia przynależności do grupy (Skrzypczak 2016, s. 32-33; por. Maffesoli 2008). 
Wspólnota umożliwia człowiekowi kształtowanie pozytywnych wartości (społecznych) przy jednoczesnym zachowaniu jego własnej wolności. W przeciwieństwie do liberalnych instytucji, które mają charakter instrumentalny, ukierunkowany na pozyskiwanie dóbr zewnętrznych, wspólnoty są wartościowe w wymiarze wewnętrznym, aksjologicznym. Dlatego istnieje silna potrzeba podejmowania takich działań, także edukacyjnych, które przywrócą społeczeństwom demokratycznym zagubione wymiary wspólnotowości, solidarności, sprawiedliwości społecznej, odpowiedzialności za losy innych ludzi, również w aspekcie globalnym (Skrzypczak, s. 64-65; por. Etzioni 1968, s. 466-467). W rozumieniu Zygmunta Baumana, chodzi o globalny wymiar odpowiedzialności moralnej za cały świat, rozciągniętej na „wspólnotę ludów i narodów” (Bauman 2007, s. 365). Wspólnota jest tutaj rozumiana jako źródło konsensusu, ponieważ w jej ramach realizuje się trudny i skomplikowany proces renegocjacji pomiędzy potrzebami całego społeczeństwa (globalnego) a potrzebami jednostki.

Edukacja dla zrównoważonego rozwoju zajmuje się zatem zagadnieniami społecznymi, takimi jak: zdrowie, prawa człowieka, różnorodność kulturowa, walka z ubóstwem, system wartości. Próbuje wskazać pewien model życia w globalnym społeczeństwie. Konstruowanie wzorca życia społecznego jest bardzo ważnym wymiarem założeń zrównoważonego rozwoju. Chodzi tu o takie sposoby działań, które będą umożliwiały rozwiązywanie konfliktów społecznych, zwłaszcza w sytuacjach rozwarstwiania się społeczeństwa. Tadeusz Pilch zwraca uwagę na to, że dominująca współcześnie filozofia neoliberalnego rozwoju państwa rodzi niedomogi i zagrożenia dla życia społecznego. Zasada rywalizacji jako naczelna reguła neoliberalnego rynku, przeniesiona na grunt relacji międzyludzkich, tworzy egoizm, ucieczkę od współdziałania, zrywa więzi międzyosobowe, powoduje obojętność na humanitarne konteksty zdarzeń i procesów, lekceważy szerszą perspektywę rozwoju czy buduje „ubóstwo w powiązania międzyludzkie” (Pilch 2013a, s. 11-13). W związku z powyższą diagnozą istnieje realna potrzeba budowania takiego systemu społecznego, który umożliwiałby zapobieganie konfliktom wynikającym z nieharmonijnego, czyli niezrównoważonego rozwoju jednostek i społeczności (Kronenberg, Bergier 2010, s. 377).

W przekonaniu Z. Baumana, remedium na tak funkcjonujący zglobalizowany świat, zagrażający podmiotowości i tożsamości człowieka, w którym odczuwa on swoje zagubienie, stanowi "globalizacja zasad etycznych” (Bauman, s. 362-365). Chodzi tutaj o taki rodzaj globalizacji, który będzie opierał się na solidarności, odpowiedzialności społecznej i międzyludzkim pokoju. Jeśli jednak przywołany postulat nie stanie się wyzwaniem dla edukacji, przede wszystkim w obszarze edukacji globalnej, pozostanie tylko kolejną utopią. Trzeba zatem podejmować działania o charakterze edukacyjnym, które będą prowadziły do budowania wspólnoty ludzkiej opartej na pewnego rodzaju moralnej odpowiedzialności za przyszłość świata (Theiss, s. 19-20). Jej tworzenie z perspektywy edukacyjnej wymaga 
odwołania się do takich lub innych wartości, na podstawie których można kształtować określone postawy.

Edukacja dla zrównoważonego rozwoju może więc służyć kształtowaniu następujących postaw społecznych:

1. Postawy solidarności. Jest to jedna z podstawowych postaw społecznych w życiu człowieka. Godny uwagi w tym zakresie jest punkt widzenia katolickiej nauki społecznej, który postawę solidarności postrzega w ścisłej relacji z dobrem wspólnym. Nauczanie Kościoła Katolickiego w tym względzie przyjmuje, że dobro wspólne jest zarazem celem i racją formalną każdej społeczności. Józef Majka twierdzi, że celowość dobra wspólnego może być rozważana jako „pewien idealny stan społeczności, już to jako pewien zespół dóbr materialnych lub moralnych" (Majka 1982, s. 151). Jako zaś racja formalna społeczności, w przekonaniu wspomnianego autora, „dobro wspólne jest procesem, w wyniku którego cała społeczność oraz poszczególni jej członkowie osiągają stan doskonałości, pożądany zarówno dla całości, jak i dla poszczególnych osób ludzkich” (Tamże). Nie wdając się w szczegółowe analizy, można przyjąć, że każda wspólnota, rodzinna, czy szerzej - środowisko społeczne - posiada coś, co jest dobrem wspólnym. Postawa solidarności będzie tu rozumiana jako zatroskanie jednostki o dobro wspólne, przy zachowaniu świadomości, że jest to jednocześnie jej dobro. Postawa solidarności w wymiarze sąsiedzkim zakłada potrzebę budowania wspólnoty lokalnej, ponieważ tylko na płaszczyźnie identyfikacji wspólnoty rodzi się świadomość wspólnego dobra (Skorowski 1994, s. 83).

Edukacja dla zrównoważonego rozwoju promuje także ideę kultury solidaryzmu w obrębie wspólnoty międzynarodowej. Chodzi tutaj o gotowość dzielenia się dobrami mieszkańców z krajów rozwiniętych, tzw. Globalnej Północy z mieszkańcami Globalnego Południa. Na konieczność kształtowania postaw solidarności zwraca uwagę także ONZ. Deklaracja Milenijna określa solidarność międzynarodową jako „jedną z podstawowych wartości w stosunkach międzynarodowych w XXI wieku, gdzie ci, którzy cierpią bądź odnoszą w istniejącym porządku gospodarczym mniejsze korzyści, zasługują na pomoc tych, którzy odnoszą największe korzyści. Stąd w kontekście globalizacji i wyzwania, jakim są wzrastające nierówności, wspieranie idei międzynarodowej solidarności jest nieodzowne”. Propagowanie solidarności globalnej i podnoszenie świadomości w zakresie współodpowiedzialności za jakość życia innych ludzi jest istotnym zadaniem edukacji na rzecz zrównoważonego rozwoju. Wartość globalnej solidarności, tzn. odpowiedzialności za innych, przejawia się w poczuciu powinności wobec drugiego człowieka.

2. Postawa sprawiedliwości. W pierwszym rzędzie wyraża się w wewnętrznym przekonaniu jednostki o wadze poszanowania prawa drugiego człowieka do określonych wartości i dóbr, które przynależą do niego na mocy jego człowieczeństwa. W praktyce postawa sprawiedliwości będzie przybierała różne formy. W jednym przypadku może mieć charakter poszanowania dóbr 
osobowych, np. wolności, samodzielności, dobrego imienia itp, w innym zaś może chodzić o bezwzględne poszanowanie zdrowia i życia drugiego człowieka. Może też odnosić się do poszanowania dóbr materialnych, np. poszanowanie cudzej własności (Skorowski 1994, s. 89). Tak rozumiana postawa sprawiedliwości jest uszczegółowieniem i ukonkretnieniem miłości. Sprawiedliwość należy do wartości fundamentalnych, ponieważ jej urzeczywistnienie w danym społeczeństwie przesądza o relacjach interpersonalnych. Budowanie współczesnego globalnego świata na zasadzie sprawiedliwości, zwłaszcza sprawiedliwości społecznej, stwarza realną szansę dla integralnego rozwoju człowieka i środowiska społecznego oraz chroni go przed zagrożeniami wszelkiego rodzaju zniewolenia.

Warto zauważyć, że idea sprawiedliwości społecznej jest bardzo mocno osadzona $\mathrm{w}$ zachodniej literaturze $\mathrm{z}$ zakresu edukacji globalnej i w praktyce organizacji pozarządowych działających na tym polu. Zupełnie inaczej sprawa przedstawia się na gruncie polskim. Z badań Magdaleny Kulety-Hulboj wynika, że polskie środowisko pozarządowe zajmujące się edukacją globalną bardzo sporadycznie odwołuje się do kategorii sprawiedliwości społecznej. Autorka stwierdza: „Dokładniejsza analiza kategorii «sprawiedliwości» w wywiadach pokazuje, że funkcjonuje ona jak puste hasło, niewiele znaczący slogan, pojawiający się w wypowiedziach badanych najczęściej w kontekście sprawiedliwego handlu jako jednego z tematów edukacji globalnej" (Kuleta-Hulboj 2017, s. 124 ).

Kształtowanie postawy sprawiedliwości społecznej w ramach edukacji dla zrównoważonego rozwoju ma na celu promowanie dóbr społecznych, takich jak: wolność i równość, dochód i bogactwo oraz tego wszystkiego, co stanowi podstawę poczucia własnej wartości. Sprawiedliwość oznacza w tym kontekście uczciwość, która przyznaje każdej osobie ludzkiej pełnię wolności i daje jej szanse na godne życie. W świetle nauczania Kościoła Katolickiego idea sprawiedliwości społecznej jest ściśle związana z ideą solidarności, określaną również jako „przyjaźń” czy „miłość społeczna”. Sprawiedliwość społeczna, wyrażająca się w postawie solidarności, stanowi wybitnie chrześcijańską cnotę, która urzeczywistnia partycypację w dobrach duchowych w większym stopniu niż w materialnych (Babicki 2017b, s. 134-137).

3. Postawa dialogu. Dialog jest warunkiem koniecznym we wzajemnych relacjach interpersonalnych. W przekonaniu Janusza Tarnowskiego, dialog oznacza „sposób komunikacji międzyludzkiej, w której podmioty (pojedyncze lub zbiorowe) dążą zwłaszcza przez słowo do wzajemnego zrozumienia, zbliżenia się i współdziałania” (Tarnowski 1983, s. 84). Przywołany autor twierdzi, że każdy dialog jest w jakimś sensie wychowawczy, ponieważ powinien stanowić pomoc dla wychowawcy i wychowanka w pełniejszym stawaniu się ludźmi. Zaś celem wychowania jest rozbudzanie duchowości dziecka przy pomocy dialogu i autentyzmu wychowawcy. Twórca teorii wychowania personalistyczno-egzystencjalnego przekonuje, że istotnym komponentem prawdziwego procesu wychowawczego jest immanentnie 
tkwiący w nim stosunek „człowieka do człowieka” (Tarnowski 2005, s. 67). Pierwszym ważnym elementem dialogu jest nawiązanie kontaktu $\mathrm{z}$ drugim człowiekiem lub wspólnotą ludzi, inaczej mówiąc, musi dojść do spotkania. Chodzi tutaj o pokonanie postawy izolowania się jednego człowieka przed drugim. Ważnym elementem dialogu jest również dążenie do prawdy. Problem jednak polega na tym, że żaden człowiek nie posiada pełni prawdy, a jedynie się do niej zbliża. Finalnym elementem dialogu jest porozumienie, do którego należy dążyć poprzez wspólne dochodzenie do prawdy. Dopiero ono, choćby częściowe, otwiera drogę do współdziałania na rzecz wspólnego dobra.

Kształtowanie postawy dialogu staje się szczególnie ważne w obliczu funkcjonowania współczesnych społeczeństw, które są coraz bardziej wielokulturowe. Umiejętność łagodzenia i rozwiązywania ewentualnych konfliktów zależeć będzie od zachodzących w tych społeczeństwach procesów demokratyzacji, wzajemnego porozumiewania się, dialogu i tolerancji. Dialog staje się więc warunkiem osobistego rozwoju, przestrzenią dla kształtowania się kultury pokoju i płaszczyzną do budowania wspólnoty. Jerzy Nikitorowicz podkreśla, że prawdziwa wspólnota szanuje odmienność kulturową, uwzględnia różnorodność. Pojawiające się we wspólnocie konflikty można rozwiązywać za pomocą wspólnie wypracowanych metod, unikając antagonizmów i przemocy. Jednak podstawową kwestią w tym względzie jest dialog zmierzający do przezwyciężania lęków, uprzedzeń czy barier. Autor stwierdza: „Jeżeli przyjmiemy, że idea dialogu zawiera się immanentnie w edukacji, to istotę dialogu międzykulturowego stanowi dostrzeganie odmienności i wyłączności człowieka przez poznawanie jego osoby na drodze bezpośredniego, podmiotowego, humanistycznego podejścia”. [...] Uważam, że wzajemne oswajanie, uwrażliwianie i pokojowe wspólistnienie jest możliwe przez aktywne uczestnictwo w trzech rodzajach dialogu: informacyjnym (przekaz, ciekawość poznawcza, porozumienie w przekazie), negocjacyjnym (poszukiwanie wzajemnego zrozumienia, kompromis, otwartość, wyjście naprzeciw odmiennym stanowiskom) oraz w dialogu traktowanym jako imperatyw, warunek pokoju i rozwoju (aktywna wymiana myśli, tolerancja, zaangażowanie w procesie wzajemnego ubogacania, otwartość)" (Nikitorowicz 2006, s. 62-64). W tak rozumianej edukacji konieczne jest współuczestnictwo w procesie otwierania się na siebie i drugiego człowieka.

4. Postawa tolerancji. Każde społeczeństwo charakteryzuje się większą lub mniejszą różnorodnością. Dotyczy to różnych obszarów życia społecznego, np. światopoglądu, wyznawanej religii, narodowości czy też etniczności. Postawa tolerancji zajmuje jedno z pierwszych miejsc we współczesnych katalogach zasad życia społecznego (Wichrowicz 1982, s. 373). To właśnie ona normuje współżycie ludzi w danym społeczeństwie. Oznacza uznanie prawa drugiego człowieka (innych) do wyrażania swoich ideałów na równi z własnymi racjami. Tak rozumiana tolerancja ma służyć budowaniu światowego pokoju, co znalazło swój wyraz w Deklaracji Zasad Tolerancji UNESCO, 
w której czytamy: „Tolerancja to szacunek, akceptacja i docenienie różnorodności naszych światowych kultur, naszych form wyrazu i sposobów bycia człowiekiem. Sprzyja jej wiedza, otwartość, komunikowanie oraz wolność myślenia, sumienia i przekonań. Tolerancja to harmonia w zróżnicowaniu. To nie tylko moralna powinność, ale także polityczny i prawny wymóg. Tolerancja - cnota, która umożliwia pokój - przyczynia się do zastępowania kultury wojny kulturą pokoju. [...] Edukacja to najskuteczniejszy sposób zapobiegania nietolerancji” (Deklaracja Zasad Tolerancji). Bez wątpienia tolerancja jest wielką i wzniosłą ideą. Warto przy tym zaznaczyć, na co zwraca uwagę Herbert Kopiec, że „tolerancja jest potrzebna, kiedy o tym, co prawdziwe, nie mamy pewnej wiedzy, lub przedmiot sporu jest taki, że wyklucza dojście do pozytywnych uzgodnień. Nie może to jednak prowadzić do usprawiedliwiania (tolerowania) prób zamazywania różnicy między dobrem a złem oraz zobojętnienia wobec poszukiwania prawdy" (Kopiec 2004, s. 73). Oznacza to, że tolerancja nie może być rozumiana jako ślepa intelektualnie i moralnie wyrozumiałość. Nie można bowiem ignorować, czy wręcz odrzucać starań zmierzających do poznania prawdy i rezygnować z rzetelnego odróżniania dobra od zła.

Czy tolerancja oznacza uznanie poglądów i zachowań innych za właściwe tylko $\mathrm{z}$ tego powodu, że one istnieją? Czy jest zatem jakaś granica tolerancji? Dla $\mathrm{H}$. Kopca tą granicą jest „kategoria prawdy, w tym prawdy o człowieku i jego godności. Nie może być tolerancji wobec zbrodni, przemocy, zdrady, kłamstwa, korupcji, swobodnego bredzenia, matactwa, głupoty, pogardy dla człowieka, jego praw i przyrodzonej godności. Tak opacznie pojęta tolerancja jest zaprzeczeniem samej siebie" (Kopiec 2004, s. 78). Przekroczenie tej granicy powoduje, że tolerancja przestaje być cnotą. W podobnym tonie wypowiada się T. Pilch, gdy mówi, że „tolerancja wówczas ma sens pozytywny, gdy jest racjonalna, aktywna poznawczo i aktywnie zaangażowana na rzecz obiektywnego dobra. Ma znaczenie negatywne, gdy jest pasywna wobec ewidentnego zła [...] Tolerancję od cierpliwości, pobłażliwości, obojętności odróżnia świadomość, że jest to określona postawa indywidualna wobec otoczenia regulowana elementami intelektualno-poznawczymi, emocjonalnymi, motywacyjnymi i etycznymi. To dzięki obecności tych czynników tolerancja zyskuje atrybut cechy nabywanej w drodze wychowania" (Pilch 2013b, s. 245).

Tolerancja powinna również charakteryzować postawę chrześcijanina. U podstaw postawy tolerancji leży przekonanie, że wszyscy ludzie są równi co do godności. Chrześcijaństwo wzmacnia tę naturalną przyrodzoną ludzką godność pojęciem godności nadprzyrodzonej. Takie ujęcie godności człowieka wynika z faktu Wcielenia i Odkupienia człowieka przez Boga, jak też z podobieństwa do Niego. Tak rozumiana godność osoby ludzkiej czyni nas równymi, mimo iż zazwyczaj dzieli nas wiele ludzkich spraw. Uogólniając, postawa tolerancji wyraża się w przyznaniu drugiemu człowiekowi praw do posiadania, wypowiadania i manifestowania własnych przekonań, a także do zgodnych z nimi zachowań (Skorowski, s. 112). 
Postawa tolerancji we współczesnym świecie określa tożsamość chrześcijanina, ponieważ jest uszczegółowieniem ewangelicznej miłości, która nakazuje szanować każdego człowieka.

5. Postawa zaangażowania na rzecz pokoju. Pokój jest fundamentalnym dobrem człowieka, jest dobrem powszechnie uznanym. Jeśli zatem pokój jest podstawowym dobrem i wartością, staje się jednocześnie podstawowym zobowiązaniem każdego społeczeństwa i całej ludzkości do podejmowania wysiłków nad zabezpieczaniem i utrwalaniem własnego istnienia. Paweł Góralczyk stwierdza: „Niepewność tej wartości (pokoju) i nieustana obawa przed ewentualną wojną stanowi moralne wezwanie dla wszystkich ludzi dobrej woli, tym bardziej dla chrześcijan, o podejmowanie wszystkich działań w celu zabezpieczenia tego dobra dla świata. Zakwestionowanie bowiem tej wartości godzi najdrastyczniej w interesy wszystkich obywateli naszego globu. W sytuacji bowiem niepokoju zostają bowiem podważone fundamentalne prawa osoby ludzkiej, a zwłaszcza - oprócz wielorakiej ruiny moralnie doniosłych wartości - zagrożona zostaje najwyższa wartość w życiu doczesnym człowieka, wartość życia. Pokój jest więc wartością samą w sobie, a tym samym staje się powinnością wszystkich ludzi" (Góralczyk 1989, s. 114). W świetle tej wypowiedzi staje się oczywiste, że postawa zaangażowania na rzecz pokoju jest obowiązkiem każdego człowieka wierzącego, ponieważ jest osadzona w miłości ewangelicznej. Jest też jedynie właściwym sposobem życia chrześcijanina. Postawa pokoju ma podwójny wymiar: wewnętrzny i zewnętrzny. Wymiar wewnętrzny jest stałym nastawieniem człowieka na poszanowanie obiektywnych wartości moralnych i społecznych. Wymiar zewnętrzny odnosi się do działania człowieka, które ma charakter zabezpieczenia i poszanowania tych wartości w ramach życia codziennego (Skorowski 1994, s. 127). W ten właśnie sposób postawa zaangażowania na rzecz pokoju buduje harmonię współżycia z samym sobą, z drugim człowiekiem, ze wspólnotą i społecznością oraz ze światem. Jednak pierwszym elementem w postawie pokoju jest stan świadomości moralnej osoby ludzkiej. Aby osiągnąć pokój, człowiek musi uformować w sobie określony stan świadomości moralnej, tzn. uznanie i zaakceptowanie obiektywnego świata wartości moralnych i społecznych.

Przyszłość świata w znacznej mierze zależy od aktywnego zaangażowania poszczególnych jednostek i całych społeczeństw na rzecz obrony pokoju. Drogą do tego celu jest edukacja, która pozwala zrozumieć charakter, złożoność i tendencje rozwojowe współczesnego świata, oraz, co ważne, kierować tym rozwojem. Wymaga to poszukiwania nowych koncepcji wychowawczych i skutecznych praktyk edukacyjnych rozumianych w kategoriach dobra społecznego (Babicki 2017a, s. 212). Według UNESCO edukacja na rzecz pokoju oznacza różnorodną aktywność ukierunkowaną na promowanie kultury pokoju. Chodzi o to, aby w procesie edukacji ukazywać młodym ludziom pokój jako wartość, kształtując w nich postawy 
i zachowania go wspierające. Ma to prowadzić do uczenia sposobów rozwiązywania konfliktów na drodze dialogu, porozumienia, przy unikaniu stosowania aktów przemocy (UNESCO 2002). Zadania, jakie wyznacza sobie edukacja dla zrównoważonego rozwoju, obejmują także te, które zmierzają do promowania wiedzy, umiejętności i kompetencji społecznych koniecznych dla realizacji procesu budowania pokoju na świecie. Odnoszą się one zarówno do działań profilaktycznych (zapobiegania konfliktom i przemocy), jak i kompensacyjnych (pomocy rozwojowej, wyrównywania szans edukacyjnych).

\section{Posumowanie}

Zadaniem współczesnej edukacji jest przygotowanie jednostek i grup społecznych do funkcjonowania w szybko zmieniającym się i zglobalizowanym świecie. Jacques Delors w opublikowanym w latach 9o. XX wieku raporcie dla UNESCO, autorstwa Międzynarodowej Komisji ds. Edukacji, uzasadniał tezę, że wprawdzie edukacja nie stanowi panaceum na wszystkie problemy świata, to jednak jest najważniejszym i najskuteczniejszym środkiem prowadzącym do rozwoju jednostek i postępu cywilizacyjnego oraz zachowania sprawiedliwości społecznej (Delors 1998). Budowanie społeczeństwa obywatelskiego, zdolnego brać odpowiedzialność za zrównoważony rozwój w wymiarze lokalnym i globalnym wymaga odpowiedniej edukacji. Kształcenie i wychowywanie społeczeństw w zakresie zrównoważonego rozwoju staje się jednym z kluczowych elementów w strategii radzenia sobie z globalnymi wyzwaniami. Dlatego celem edukacji dla zrównoważonego rozwoju jest kształtowanie określonych postaw społecznych. Budowanie takich postaw można oprzeć na chrześcijańskim systemie wartości, w którym na czoło wysuwa się integralna koncepcja człowieka. W takim ujęciu człowiek charakteryzuje się godnością, wewnętrzną relacyjnością, solidarnością, braterstwem i gotowością do wspólnego działania. Taki człowiek odrzuca indywidualizm, konsumpcjonizm, hedonizm, egoizm, wybiera natomiast szacunek, solidarność i sprawiedliwość społeczną oraz dobro wspólne. Edukacja dla zrównoważonego rozwoju w oparciu o wartości społeczne pomoże przygotować ludzi do życia w zglobalizowanym, pełnym współzależności świecie, w taki sposób, aby potrafili nie tylko się do niego sprawnie adaptować, ale także kształtować go i nadawać mu bardziej humanistyczne oblicze.

\section{Bibliografia}

Babicki Z. (2016). Praktyczny wymiar edukacji globalnej. W: Babicki Z., Kuleta-Hulboj M. (red.). Teoretyczne i praktyczne konteksty edukacji globalnej. Warszawa: Wydawnictwo UKSW.

Babicki Z. (2017a). Idea wychowania do pokoju w programach pomocowych dzieciom w Afryce. „Forum Pedagogiczne”, nr 1, s. 211-226. 
Babicki Z. (2017b). Sprawiedliwość społeczna w założeniach i działaniach sprawiedliwego handlu. „Forum Pedagogiczne”, nr 2, s. 133-144.

Bauman Z. (2007). Szanse etyki w zglobalizowanym świecie. Kraków: Wydawnictwo "Znak”.

Braidotti R. (2014). Po człowieku. Warszawa: Wydawnictwo PWN.

Cichosz M. (2014). Środowisko/środowisko wychowawcze - dorobek, kierunki przemian - współczesne wyzwania. W: Danilewicz W., Theiss W. (red.). Pedagogika społeczna wobec zagrożeń człowieka i idei sprawiedliwości społecznej. Warszawa: „Żak” Wydawnictwo Edukacyjne Z. Dobkowskiej.

Delors J. (1998). Edukacja - jest w niej ukryty skarb. Raport dla UNESCO Międzynarodowej Komisji do spraw Edukacji dla XXI wieku. Warszawa: Wydawnictwo Akademickie „Żak”.

Deklaracja Zasad Tolerancji, Ogłoszona i podpisana przez państwa członkowskie UNESCO

16 listopada 1995, dostępny na: https://portal.tezeusz.pl (otwarto: 6.11.2018).

Etzioni A. (1968). The Active Society: A Theory of Societal and Political Process. New York: Collier-Macmillan.

Góralczyk P. (1989). Chrześcijanin budowniczym pokoju. „Communio”, nr 5, s. 114-126.

http://www.unesco.pl (otwarto: 8.06.2018).

http://www.un.org (otwarto: 25.10.2018).

Kopiec H. (2004). W kręgu nadziei i pułapek tolerancji. W: Niewęgłowski J. (red.). W trosce o młodzież. Edukacja-praca-obywatelstwo. Warszawa: Wydawnictwo Salezjańskie.

Kronenberg J. Bergier T. (2010). Wyzwania zrównoważonego rozwoju w Polce. Kraków: Wydawnictwo Fundacja Sendzimira.

Kuleta-Hulboj M. (2017). Sprawiedliwość i odpowiedzialność w edukacji globalnej ( $w$ narracjach przedstawicieli organizacji pozarzadowych). „Forum Pedagogiczne", nr 2, s. 119-132.

Maffesoli M. (2008). Czas plemion. Schyłek indywidualizmu w czasach ponowoczesnych. Warszawa: Wydawnictwo Naukowe PWN.

Majka J. (1982). Filozofia społeczna. Wrocław: Wydawnictwo Wrocławskiej Księgarni Archidiecezjalnej.

Nikitorowicz J. (2006). Pedagog społeczny w warunkach wielokulturowości i potrzeby kreowania przestrzeni międzykulturowego dialogu. W: Kozdrowicz E., Przecławska A. (red.). Absolwent pedagogiki dziś. Perspektywa teorii i praktyki pedagogiki społecznej. Warszawa: Wydawnictwo Akademickie Żak.

Odrowąż-Coates A. (2015). Is gender neutrality a post-human phenomenon? The concept of 'gender neutral' in Swedish education. "Journal of Gender and Power”, nr. 1, vol. 3, s. 113-133. 
Pilch T. (2013a). Wprowadzenie. W: Pilch T., Sosnowski T. (red.). Zagrożenia człowieka i idei sprawiedliwości społecznej. Warszawa: Wydawnictwo Akademickie „Żak”.

Pilch T. (2013b). Polska nietolerancja. W: Pilch T., Sosnowski T. (red.). Zagrożenia człowieka i idei sprawiedliwości społecznej. Warszawa: Wydawnictwo Akademickie Żak.

Rogall H. (2010). Ekonomia zrównoważonego rozwoju. Teoria i praktyka. Poznań: Wydawnictwo Zysk i s-ka.

Scheunpflug A. (2004). Learning and skills for a global society: the education context. W: O'Loughlin E., Wegimont L. (red.). Learning for a global society. Evaluation and quality in global education. Proceedings of the GENE Conference. Lisbon.

Skorowski H. (1994). Być chrześcijaninem i obywatelem dziś. Refleksje o postawach moralno-społecznych. Warszawa: Wydawnictwo Salezjańskie.

Skrzypczak B. (2016). Współczynnik społecznościowy. Edukacyjne (re)konstruowanie instytucji społecznościowych - w perspektywie pedagogiki społecznej. Toruń: Wydawnictwo Edukacyjne Akapit.

Szadzińska E. (2015). Proces kształcenia ukierunkowany na wartości społeczne. W: Kuleta-Hulboj M., Gontarska M. (red.). Edukacja globalna. Polskie konteksty i inspiracje. Wrocław: Wydawnictwo Naukowe Dolnośląskiej Szkoły Wyższej.

Tarnowski J. (1983). Dialog z młodymi. „Communio”, nr 4, s. 80-92.

Tarnowski J. (2005). Chrześcijańska pedagogika personalno-egzystencjalna. W: Śliwerski B. (red.). Współczesne teorie i nurty wychowania. Kraków: Oficyna Wydawnicza „Impuls”.

Theiss W. (2016). Solidarność globalna i zadania edukacji (Czytając Baumana). W: Babicki Z., Kuleta-Hulboj M. (red.). Teoretyczne i praktyczne konteksty edukacji globalnej. Warszawa: Wydawnictwo UKSW.

Tönnies F. (1988). Wspólnota i stowarzyszenie. Warszawa: Wydawnictwo PWN.

UNESCO. (2002). The culture of peace. Paryż: Wydawnictwo UNICEF.

Wichrowicz J. (1982). Tolerancja. W: Pawlak Z. (red.). Katolicyzm A-Z. Poznań: Księgarnia św. Wojciecha.

Zawojski P. (2017). Posthumanizm, czyli humanizm naszych czasów. „Kultura i Historia”, nr 32, s. 68-76.

\section{SOCIAL VALUES IN EDUCATION FOR SUSTAINABLE DEVELOPMENT}

\footnotetext{
Abstract: Education for sustainable development is an important social strategy that aims to support the necessary changes as a response to the global socio-economic threats of the modern world. It emphasizes the need for a holistic approach combining development problems with social and environmental issues. The aim of the article is to show the need and significance of the presence of social values in the idea of sustainable development,
} 
which through education is aimed at inducing local and global changes in people. These changes are to lead to building a better world based on greater integration with the environment and a just society for present and future generations.

Keywords: sustainable development; education for sustainable development; social values; environment; community; common good.

Zbigniew Babicki - doktor nauk społecznych w zakresie pedagogiki, adiunkt na Wydziale Nauk Pedagogicznych Uniwersytetu Kardynała Stefana Wyszyńskiego w Warszawie w Katedrze Pedagogiki Społecznej i Pedagogiki Pracy. Swoimi zainteresowaniami naukowymi obejmuje takie subdyscypliny pedagogiczne, jak: pedagogika społeczna i pedagogika opiekuńcza. Adres korespondencyjny: ul. Wóycickiego 1/3, 01-938 Warszawa. Adres e-mailowy: z.babicki@uksw.edu.pl. 